\title{
ANSERJ
}

Vol. 12, No. 2

Autumn / automne 2021

pp. $45-57$

Canadian Journal of Nonprofit and Social Economy Research

Revue canadienne de recherche sur les OSBL et l'économie sociale

\section{What Constitutes a New Nonprofit? Investigating Nonprofit Organizational Founding Dates}

\author{
Jamie Levine Daniel \& Fredrik O. Andersson \\ Indiana University-Purdue University Indianapolis
}

\begin{abstract}
The question of when a new nonprofit is founded has not been pursued with sufficient precision. Specifically, a fundamental challenge facing any nonprofit researcher planning to detect, isolate, and analyze new nonprofits is that nonprofit founding is a process, not a discrete event. This study uses administrative data that includes three different founding indicators from more than 4,000 arts organizations, supplemented with survey data from 242 organizations, to illustrate some of the problems inherent in treating the founding process as one discrete event. It also elevates the voices of founders to demonstrate their conceptualization of the concept and offer insights into the multidimensionality of founding.
\end{abstract}

\section{RÉSUMÉ}

Jusqu'à présent, les chercheurs n'ont pas poursuivi avec assez de précision la question du moment de fondation d'un nouvel organisme sans but lucratif (OSBL). Plus précisément, tout chercheur voulant détecter, isoler et analyser de nouveaux OSBL fait face à un défi fondamental, le fait que la fondation d'un nouvel OSBL soit un processus plutôt qu'un événement spécifique. Cette étude utilise des données administratives provenant de plus de 4000 organisations artistiques et comportant trois mesures de fondation différentes, complétées par des données sur des sondages effectués auprès de 242 organisations, afin d'illustrer certains des problèmes soulevés quand on traite le processus de fondation comme s'il était un événement ponctuel. L'étude donne aussi la parole aux fondateurs pour démontrer comment ceuxci envisagent le concept de fondation et pour souligner la pluridimensionnalité des processus de fondation.

Keywords / Mots clés : Nonprofit; Founding; Entrepreneurship; Organization life cycle / Organisme sans but lucratif, Fondation, Entreprenariat, Cycle de vie d'une organisation

\section{INTRODUCTION}

New nonprofit organizations offer many benefits to their communities. They help address emerging needs (Lecy, Van Slyke, \& Yoon, 2016); spur new thinking, innovation, and employment; and can replace organizations that are closing (Kachlami, Davidsson, Obschonka, Yazdanfar, \& Lundström, 2020; Lecy, Van Slyke, \& Yoon, 2016). Identifying newly founded organizations is challenging, however, because the definition of founding is nebulous. 


\section{Levine Daniel \& Andersson (2021)}

The seemingly straightforward question, "When is a nonprofit founded?" implies founding is a singular event. The concept of "nonprofit organization," however, contains a multitude of definitions, and different nonprofits are founded for different reasons by different individuals and/or groups. Some nonprofits remain informal entities for perpetuity, whereas others run the gamut of formalization from the idea stage to incorporated, to tax exempt within a short time. For others, the formalization steps may occur over a much longer period, and they may, for example, elect to incorporate but never obtain tax-exempt status.

For those organizations that do reach these milestones, however, what does founding mean, and who decides? A researcher may have one idea, a practitioner may have another, a lawyer or regulator may have a third conceptualization, and so on. Treating founding as a concept with only one meaning —and, therefore, one concrete way to measure-may be convenient for scholars, especially when it comes to data availability and collection. However, the motivation underlying this question belies its complexity. Is the goal to understand the nascent stages of an organization's life cycle, including if and when it formalizes as an institution according to certain benchmarks or milestones, or is the goal to simply identify new nonprofits to map the sector? Even this question is complex. Is it the landscape of formalized institutions that is of interest, or rather what type of work that is being down on the ground and for whose benefit? Each of these questions approaches the concept of founding differently, and has implications for how we define, measure, and understand nonprofit founding.

A fundamental challenge facing any nonprofit researcher wanting to detect and isolate new nonprofits is that founding cannot be depicted as a discrete event but rather as a process transpiring over time (Andersson, 2017). In other words, the question of when a new nonprofit is founded is intimately connected to the choice and determination made by the questioner of what constitutes founding. In addition, it is important to examine who is asking the question, and why. Whose voices are missing from among those defining the concept? Making founding synonymous with an external benchmark of formalization removes agency from key internal stakeholders to determine when the organization came into being; it may also overlook a history of community work and relationships because of a lack of formalized status.

This article uses both administrative and survey data to examine the multidimensional meaning of founding from a research perspective. It focuses on organizations that have pursued multiple administrative milestones of formalization, including incorporation and tax exemption. First, administrative data from over 4,000 arts organizations is analyzed to explore three different founding indicators. The organizations were surveyed about what founding means, and insights from over 200 responses were used as a comparative assessment. The article showcases the multidimensionality of nonprofit founding and illustrates some of the issues associated with the use of public administrative data to determine founding, including the variation in the meaning of founding between internal stakeholders and external and/or non-affiliated entities (i.e., researchers). The findings support the idea of founding as an ongoing process rather than a discrete event. They also illuminate the dynamic nature of nonprofit founding and bring forward several questions for future inquiry.

These findings are especially relevant in these turbulent times, as the sector attempts to recover from the effects of both a global pandemic and social justice protests that underscore the sector's contributions to institutionalized racism and efforts to address it. As Cathy Barr (2020) notes, there is a need for research on "the needs currently being met-or left unmet—by social purpose organizations" (p. 7). As health care and social justice needs scale up, they are likely being met by new nonprofits. Adhering to a definition that links founding to formalized milestones means these organizations will not be identified or mapped in real time, distorting the picture of who is doing what in terms of service provision. This also has implications for practice. Organizations need access to funding, for example, but may face barriers such as a requirement to have been established for a certain number of years. This emphasis on formality, as defined by certain actors, disadvantages organizations that have been established and acting on the ground, regardless of their administrative status. 


\section{Levine Daniel \& Andersson (2021)}

The following section provides an overview of the research on nonprofit founding. Methodology and findings are then presented. The article concludes with a discussion of the implications and recommendations for future research.

\section{LITERATURE REVIEW}

In the early 1980s, Dennis Young (1983) published his seminal work challenging the predominant view of nonprofit organizations as mere responses to failures by the government or market to address unmet demand. Instead, Young presented a case based on a supply side perspective where new nonprofits do not simply emerge out of thin air but are the results of purposeful action undertaken by a nonprofit entrepreneurial agent (i.e., the founder). Young's work helped form the basis for nonprofit scholars interested in nonprofit entrepreneurship (e.g., (Bilodeau \& Slivinski 1998; Cordes, Steuerle, \& Twombly 2004), the emergence and entry of new nonprofit organizations (Dollhopf \& Scheitle, 2016; Grønbjerg \& Paarlberg, 2001), and for researchers analyzing nonprofits utilizing a life-cycle perspective (e.g., Bess, 1998; Edenfield \& Andersson, 2018; Hasenfeld \& Schmid, 1989).

The creation of new nonprofits plays a central role in all these literatures. Whereas some scholars consider nonprofit founding a discrete event, others view it as a process. The former perspective is commonly found in the sizable and robust macro-oriented nonprofit literature devoted to describing and understanding the size, scope, density, and growth of the nonprofit sector (Grønbjerg \& Paarlberg, 2001; Lecy \& Van Slyke, 2013; Liu, 2017), and the subset of this literature focusing on nonprofit sector entry by analyzing the number of newly founded nonprofits in a particular region or industry (Saxton \& Benson, 2005; Twombly, 2003). The latter perspective, that founding is a process, is more prominent in the nonprofit entrepreneurship and nonprofit life-cycle research (Bess, 1998; Cordes et al., 2004; Dollhopf \& Scheitle, 2016; Edenfield \& Andersson, 2018; Lecy et al., 2016). Hence, the above-mentioned literature holds clues about how the nonprofit founding phenomenon is framed and operationalized.

Perhaps the most widespread tactic to capture the founding of new nonprofit organizations is to target some type of formalized event, such as incorporation and/or IRS registration. The basis for concentrating on such events is rooted in the assumption that formalized milestones take place at the very beginning of the life of a new nonprofit. For example, Joseph Cordes, Eugene Steuerle, and Eric C. Twombly (2004) used the IRS rule-date in their analysis of new nonprofits and argued that "although in individual cases the IRS data may capture the entry of some nonprofits with a lag, organizations that seek formal recognition from the IRS are apt to do so fairly soon after their initial 'informal' formation because formal IRS recognition confers a number of legal and tax advantages. ... Thus, using the IRS ruling date seems to be a reasonable proxy for formation of a new organization" (p. 123). As a result, a widespread approach to capture new nonprofit entry is to look to public administrative records, such as those from the IRS or the Canada Revenue Agency, and consider the entry/appearance in such records by a new nonprofit organization as the core criterion and timestamp of founding (see Cordes et al., 2004; Khovenrenkov, 2016; Khovrenkov \& Gidluck, 2017; Lecy et al., 2016; Saxton \& Benson, 2005; Sharpe, 1994; Twombly, 2003). As Eric C. Twombly (2003) states, "[n]onprofit entry occurs when an organization gains tax-exempt status from the IRS" (p. 220).

The date of incorporation is an alternative indicator also rooted in accessible public administration records. Kirsten Grønbjerg and Laurie Clerkin (2005) argue in favour of using the state corporate registries over IRS registration, as the former capture newer organizations more effectively. However, the utility of relying on the incorporation- and/or tax-exemption rule date as an indicator of nonprofit founding is questionable. The choice of which administrative record to use will lead to variation in the number of organizations identified. In an excellent article, Kirsten Grønbjerg, Helen K. Liu, and Thomas H. Pollak (2010) provide multiple reasons why a nonprofit organization may be incorporated but not registered with the IRS as a tax-exempt entity, and why IRS-registered nonprofits may not be incorporated. The discrepancy between the IRS and incorporation records has also been shown empirically (Grønbjerg \& Clerkin, 2005; Grønbjerg \& Paarlberg, 


\section{Levine Daniel \& Andersson (2021)}

2002). For example, in a robust and detailed analysis of nonprofits in the State of Indiana, Grønbjerg and Paarlberg (2002) found only 23 percent of nonprofits showing up on both state corporate records and IRS registries.

In addition, not all types of nonprofits are even captured in administrative data. For example, in the U.S., religious congregations and ancillary entities of congregation, such as daycares and food pantries, are not legally required to apply to the IRS for a recognition of exemption. Contrary to Twombly (2003), organizations do not always pursue administrative milestones such as incorporation or tax exemption immediately upon founding. Grønbjerg et al. (2010) list several factors that may result in a new nonprofit not electing to register with the IRS, such as lack of financial resources, lack of knowhow, or utilizing a fiscal sponsor. They also note how it can sometimes take a long time for a new nonprofit to obtain a final ruling from the IRS, and even longer before it appears in IRS public records as a new entry. Jesse D. Lecy and David M. Van Slyke (2016) used surveys to connect with nearly one thousand nonprofits that had recently obtained IRS tax exemption and found that half of the nonprofit entrepreneurs indicated they had been operational before registering their organizations, sometimes for several years.

Treating nonprofit founding as an ongoing process rather than a discrete event may paint a more accurate picture of organizational founding. As Erica J. Dollohopf and Christopher P. Scheitle (2016) observe, nonprofit founders may undertake a variety of organizing activities prior to considering incorporating and/or registering with a federal tax agency. Despite this recognition of multiple activities, this lens uses formalized administrative milestones (albeit multiple, rather than one) as measures of founding. This approach may be sufficient if the question of when a nonprofit is founded is motivated by an interest in capturing the creation of formal entities.

However, as David Horton Smith (1997) notes, nonprofit action is frequently organized in less formalized grassroots organizations that will never show up in public records because these entities never choose to incorporate or register with the IRS. Failing to account for informal activities discounts the work informal organizations do. For example, Kunle Akingbola (2013) sheds light on what he calls "unincorporated social economy organizations" (p.67) that highlight the integral nature of these organizations' activities to society.

The process of founding can also be observed in the nonprofit life-cycle literature, which recognizes that many undertakings in the gestation of a new nonprofit organization transpire before the new entity becomes a formal operational entity (Bess, 1998; Edenfield \& Andersson, 2018), what Fredrik O. Andersson (2017) refers to as the nascent nonprofit stage. Hence, the notion of founding is less distinct from a life-cycle perspective. Instead, the focus is on describing different phases in the evolution of a new nonprofit and comprehending the critical junctures and forces engendering such evaluation. For example, Yeheskel Hasenfeld and Hillel Schmid (1989) depicts the nascent stage as "generally informal and unsystematic" (p. 247), and Gary Bess (1998) adds that "little planning and coordination on a scale involving group members occurs" (p. 49). Whereas some ventures never evolve beyond the nascent phase, others do by developing some basic administrative and financial systems, installing a board of directors, developing at least one distinct program/service, and defining and designating work roles (see Stevens, 2008).

Accounting for the multidimensionality of nonprofit founding is critical to mapping the sector. According to Susan Appe $(2012,2013)$, researchers influence the mapping of a society through the meanings they attach and the ways they define their parameters. Therefore, it is only possible to have confidence in mapping if the data is capturing the desired activity. The same can be said for scholars trying to capture nonprofit founding. Paul C. Godfrey's (2011) categorization of organizations in the informal economy as informal, semi-informal, and formal helps break down the approach that founding occurs on a specific date. As he notes, "The study of the informal economy also provides scholars with a chance to 


\section{Levine Daniel \& Andersson (2021)}

develop constructs and dimensions fit for a complex, rather than discretely simple, conceptual world" (p. 270), underscoring the need for a better understanding of nonprofit founding.

The above observations and considerations certainly illuminate the multidimensionality of nonprofit founding. The article will now move to empirically explore one aspect of this complicated issue as it relates to organizations that have formalized to a certain degree. As noted earlier, some nonprofit scholars have deemed the IRS-rule date a reliable proxy for founding. The underlying rationale of this approach is that the choice of a founding indicator, in this case IRS-rule date, is not necessarily a significant problem if the indicator can be assumed to be in close proximity to the "real" founding date. But just how close in time are some of these founding indicators? The subsequent segment explores this question by looking at four different indicators: a subjective year-of-founding statistic, the year of incorporation, the IRS-rule year, and survey responses from key informants inside young nonprofits asked to pinpoint a year of founding. It investigates how closely coupled in time these different indicators are.

\section{THE FOUNDING OF ARTS NONPROFITS: AN EMPIRICAL EXPLORATION}

The setting for this empirical exploration is nonprofit arts organizations and the quantitative data comes from DataArts, which includes information from over 90,000 cultural data profiles posted between 2001-2019 by close to 19,000 unique nonprofit arts and culture organizations located across the United States and Canada. Representing a single fiscal year, each profile comprises a large number of data variables covering program, financial, and operational dimensions. The value and specific details of the DataArts cultural data profiles has been described in great detail elsewhere (see Kim \& Charles, 2016). For the purposes of this study, which zeroes in on organizations that have reached at least some level of formalization, the focus is on the answers to three time-related questions: What year was the organization incorporated (if applicable)? What year did the organization obtain IRS tax-exempt status (if applicable)? What year was the organization founded?

The analysis is limited to U.S.-based organizations that were founded during or after 2000, which resulted in 5,755 unique organizations that reported data for at least one of three key variables of interest: founding date, incorporation date, and IRS exemption date. Table 1 provides descriptive statistics about this initial sample, including the count of organizations at each stage. More than 73 percent $(4,215)$ of the organizations in the initial sample reported something for all three time-related questions. Approximately 20 percent $(1,125)$ only responded to one of the three time-related questions, of which the vast majority (901) only reported the IRS exemption date, only 221 reported a founding date, and only three reported an incorporation date. Approximately seven percent (415)

Table 1: Organizations by Event Counts

\begin{tabular}{|l|r|r|r|}
\hline & Frequency & Percent & $\begin{array}{c}\text { Cumulative } \\
\text { Percent }\end{array}$ \\
\hline Has date for 1 event & 1,125 & 19.55 & 19.55 \\
\hline Has date for 2 events & 415 & 7.21 & 26.76 \\
\hline Has dates for all 3 events & 4,215 & 73.24 & 100.00 \\
\hline Total & $\mathbf{5 , 7 5 5}$ & $\mathbf{1 0 0 . 0 0}$ & \\
\hline
\end{tabular}
of the initial sample responded to two of the three time-related questions, of which the vast majority reported a founding date plus another event: 134 reported founding and incorporation dates, and 235 reported founding and exemption dates. Only 46 organizations reported incorporation and exemption dates.

Multiple reasons may explain why some organizations only responded to one or two of the time-related questions. For example, the key informant filling out the DataArts profile may not have known the year of founding or incorporation but could more easily find the IRS date (e.g., through a publicly available Form 990). The profile instructions regarding the founding date may have been unclear, and/or organizations with only a founding date may not have incorporated or filed 


\section{Levine Daniel \& Andersson (2021)}

for IRS exemption. Because there is no way of knowing why these profiles are incomplete, this analysis is focused on the 4,215 organizations that reported all three dates.

A closer examination of organizations reporting all three dates suggests there is an order to events, though in some cases all the events occurred in the same year. The event sequence starts with founding followed by incorporation followed by tax exemption. However, there were a small number of cases where the date of tax exemption or incorporation preceded the date of founding, or where tax exemption preceded incorporation. While incongruities related to incorporation and tax-exemption dates may occur for a variety of reasons (Grønbjerg et al., 2010), incorporation rarely occurs before a founding date. In fact, as Jesse D. Lecy, David M. Van Slyke, and Nara Yoon (2016) show, organizations may average up to 6.5 years of voluntary or informal activity before incorporating, supporting the idea that founding encompasses coming up with an idea and is not necessarily represented by a legal milestone, budget, or activity level. Hence, for clarity of interpretation, this study assumed the following order of events: founding, incorporation, and exemption, in creating the results presented in Table 2.

Table 2: Time to Organizational Stage Change

\begin{tabular}{|l|r|r|r|r|r|}
\hline & \multicolumn{1}{|c|}{ Obs } & Mean & Std. Dev. & Min & Max \\
\hline From founding to incorporation & 4,192 & 1.114 & 1,96861 & 0 & 14 \\
\hline From founding to IRS exemption & 4,175 & 2,019 & 2.47491 & 0 & 16 \\
\hline From incorporation to IRS exemption & 4,121 & 0.941 & 1.70454 & 0 & 16 \\
\hline
\end{tabular}

The data reveals significant variation in terms of when the different events occur among the nonprofit arts organizations. Many of the organizations operated for at least a year, on average, before becoming incorporated, and an additional year, on average, between incorporation and filing for tax-exempt status. This finding reinforces the notion that nonprofit entrepreneurship is a process that transpires over time (Andersson, 2017), and that many nonprofit organizations are operational long before they formally become incorporated and/or tax-exempt entities (Lecy et al., 2016). Also, as noted earlier, scholars such as Cordes et al. (2004) argue that the IRS ruling date is a reasonable facsimile for the formation of a new nonprofit. Given the average time between informal founding and tax-exempt rule date is two years, relying on this assumption must be cautioned against if the goal is to identify and understand the emergence and formation of new nonprofits. For example, studying nonprofit entrepreneurship requires that scholars are able to capture nonprofit entrepreneurs in the process of constructing/founding nonprofit organizations, rather than nonprofit entrepreneurs running already established nonprofits organizations.

So far, this exploration of when a new nonprofit is founded has been guided by the data from the cultural data profiles in DataArts. A more direct approach would be to ask someone associated with a new nonprofit when the organization was founded, rather than relying on this type of administrative record. To bring additional insights, a survey was sent out to representatives from some of the DataArts nonprofits in the sample.

Of the 4,215 organizations that indicated a founding, incorporation, and/or IRS exemption date of 2000 or later, 1,184 first submitted a profile to DataArts in 2016 or later. This population was narrowed down in an attempt to mitigate biases associated with recall and memory decay, since respondents were being asked to reflect about the information they submitted. A total of 317 responses were received (26\% response rate), of which 244 (20.6\%) were usable. Responses were deemed unusable if they were incomplete, duplicates, and/or reported founding dates pre-2000. ${ }^{1}$ The majority of respon- 


\section{Levine Daniel \& Andersson (2021)}

dents $(55 \%)$ identified their organization's primary role (Moulton \& Eckerd, 2012) as service provision, with an additional 25 percent focusing on building social capital. Table 3 shows the breakdown of organizational role identification.

Approximately two thirds of respondents (65\%) identified themselves as the organization's founder. Of this group, 89 percent held additional roles, including but not limited to executive director/CEO and/or board member. Table 4 provides a breakdown of respondent roles. Over 34 percent of respondents had previous start-up experience, 44 percent of whom indicated for-profit startup experience, 35 percent indicated nonprofit startup experience, and 21 percent indicated startup experience in both sectors. Approximately three or four respondents $(65 \%)$ said their organizations were founded by a team of people (rather than a single individual), with an average start-up team size mean of $5.01(S D=3.46)$. The smallest team size reported was two, the largest was 20.

Each respondent was asked the following question, "When (as in which year) was this organization born?" The answer was compared with the dates indicated in DataArts file. As Table 5 shows, close to seven out of ten respondents $(69 \%)$ reported a date that matched at least one of the three discrete dates reported in the DataArts file (founding, incorporation, or IRS date).

Interestingly, the IRS rule date is the event most associated with founding when the survey answers are compared to the DataArts file data. Perhaps even more noteworthy is that 31 percent of respondents gave an organizational birth date that did not correspond to any of the DataArts dates. All respondents were offered the opportunity to elaborate on their founding by responding to this prompt: "What was the specific circumstance and/or action(s)/activities in that year that made you and organizational stakeholders say, 'Okay, this is more than just an idea, we are now an organization'?" The winsorized mean of these founding narratives
Table 3: Organizational Roles

\begin{tabular}{|l|c|c|}
\hline & Frequency & Percent \\
\hline Social provision & 120 & 54.79 \\
\hline Social capital & 54 & 24.66 \\
\hline Innovation & 27 & 12.33 \\
\hline Civic engagement & 11 & 5.02 \\
\hline Values expression & 6 & 2.74 \\
\hline Political advocacy & 1 & 0.46 \\
\hline Total & $\mathbf{2 1 9}$ & $\mathbf{1 0 0 . 0 0}$ \\
\hline
\end{tabular}

Table 4: Respondent Roles

\begin{tabular}{|l|c|c|}
\hline & Frequency & Percent \\
\hline Board chair member & 11 & 4.55 \\
\hline Board chair member + other & 4 & 1.65 \\
\hline Executive director/CEO & 44 & 18.18 \\
\hline Executive director/CEO + board & 1 & 0.41 \\
\hline Executive director/CEO + other & 4 & 1.65 \\
\hline Founder & 17 & 7.02 \\
\hline Founder + board & 9 & 3.72 \\
\hline Founder + board + other & 10 & 4.13 \\
\hline Founder + executive director/CEO & 51 & 21.07 \\
\hline Founder + executive director + board & 55 & 22.73 \\
\hline Founder + executive director + board + other & 9 & 3.72 \\
\hline Founder + executive director/CEO + other & 3 & 1.24 \\
\hline Founder + other & 4 & 1.65 \\
\hline Other & 20 & 8.26 \\
\hline Total & $\mathbf{2 4 2}$ & 100.00 \\
\hline
\end{tabular}

Table 5: Founding Dates in Surey versus DataArts Reports

\begin{tabular}{|l|c|c|}
\hline & Frequency & Percent \\
\hline Survey founding date matches DataArts IRS date & 91 & 37.60 \\
\hline Survey founding date matches DataArts founding & 48 & 19.83 \\
\hline Survey founding date matches DataArts incorporation date & 28 & 11.57 \\
\hline Survey founding date does not match DataArts date & 75 & 30.99 \\
\hline Total & 242 & 100.00 \\
\hline
\end{tabular}




\section{Levine Daniel \& Andersson (2021)}

was 35 words, with a minimum of $0(0.06 \%$ of respondents) and a maximum of 298 words. Here are some examples of the responses:

This is not how it happened. It was first an idea, funds were raised to make it a viable option, then a decision was made to go forward.

Several years of holding an annual summer folk festival that brought people together, had strong community support through volunteers and donors, as well as an interest in cultural music and arts programs that would be available year round

Went to a luncheon for Latina businesswomen at a community center in the community. Keynote speaker was the first Latina mayor in her city and the county. She started a non-profit to help the youth in her community. It was small and it eventually expanded and got her more involved in her neighborhood and to run for office. All women there were Latina $(X)$ who started a business (for profit or non-profit) out of need that was missing for themselves and or community. The small group I went with we saw the idea to create a theatre that was supportive work reflective of the Latina experience and community.

For those organizations whose survey and DataArts dates aligned, founding narratives often referred to events outside of traditionally defined origins (founding, incorporation, IRS rule date), such as a life milestone ("a family death"), the first idea ("a conversation between radio co-hosts"), or needs and opportunities that arose in the community ("we gained the support of our landlord who shared our vision"). This aligns with prior research noting that founders' interests and passions as drivers for creating nonprofits (Carman and Nesbit, 2013).

These gaps between administrative data (such as recorded dates) and survey data are not necessarily surprising. Capturing key informant characteristics can address some of these gaps (Kim \& Levine Daniel, 2020), which occurs in this survey targeting the founders of newly identified nonprofits. Still, the survey responses raise a number of new questions, such as why so many provided dates did not correspond to any of the DataArts dates, and why so many participants gravitate toward the year of the IRS rule data to answer the survey question. It is beyond this study to seek the answers to these questions. Still, contrasting the administrative data and the survey data irrefutably illuminates just how complex it is to pinpoint the true beginning of a nonprofit and the conceptual and methodological challenges facing nonprofit entrepreneurship scholars.

\section{DISCUSSION}

When is a new nonprofit organization founded? It depends; founding is multidimensional. Using a unique ability built into the DataArts profile to compare two common indicators of nonprofit founding, year of incorporation and year of obtaining IRS tax-exemption, with a third indicator denoting year founded, this study attempts to shed some much-needed light on this straightforward yet thorny question. This section will focus on a few key observations and highlight implications for current and future nonprofit research.

Research depicting nonprofit founding as a discrete event is common, driven by both practicality and convenience. Associating founding with a particular event, for example IRS ruling, not only allows researchers to timestamp the birth date of a new nonprofit but it also provides an opportunity to use public administrative records to identify newborn nonprofits. Essentially, for organizations that formalize, these formalization milestones come to mean founding. However, this article has shown that if the only undertaking or event utilized is the IRS ruling date, the founding phenomenon will not be recognized or identified until late in the emergence process. This approach will lead to many organizations being overlooked (for example, the 221 organizations in this sample that only reported a founding date, not incorporation or IRS ruling), and researchers will inevitably miss out on key features that are of great interest to explain and analyze. Two such features will be focused on and highlighted here. 


\section{Levine Daniel \& Andersson (2021)}

First, scholars have long argued that new organizations must deal with a number of complicated challenges that limit their viability (Stinchcombe, 1965). According to Howard E. Aldrich and Tiantian Yang (2012), this liability of newness is particularly potent during the nascent stage of organization creation, which suggests that many, perhaps even most, new organizations die while emerging. It is important to acknowledge there is a dearth of research focusing on the nascent stage of nonprofit organizational founding, though there are exceptions (e.g., Bess, 1998; Dollohopf \& Scheitle, 2016). Even though Stinchcombe (1965) viewed the liability of newness as a "general rule" (Aldrich \& Yang, 2012, p. 1), the situation may be different for emerging nonprofits compared to, for example, emerging business enterprises. However, one study lending support to Aldrich and Yang's (2012) main argument is Fredrik O. Andersson and Michael Ford's (2017) examination of new educational organizations in the City of Milwaukee. They analyzed public records of new nonprofit voucher school entry between 1991 and 2015 and found 70 percent of the new nonprofits never made it beyond the nascent phase. Though not the original focus of this study, this data may reflect some of this liability as well. While a choice was made to intentionally analyze organizations reporting all three dates, 27 percent of organizations in the original data set only reported one or two of the three events of interest. As noted earlier, this may be because of respondent errors or omissions, but this may also be due to a failure to reach incorporation milestones.

Clearly, more empirical research is needed to confirm the impact of the liability of newness on emerging and/or young nonprofits by examining different types of nonprofits (e.g., arts, human services) in different contexts. However, if Aldrich and Yang's (2012) proposition is accurate, and other studies align with Andersson and Ford's (2017) findings, it is likely that a significant number of emerging nonprofits exit or die before they obtain their tax exemption. Consequently, research on nonprofit founding that uses the IRS rule date as a starting point will have limited utility for those wanting to understand the challenges of new nonprofit creation, as it is only ends up capturing those nonprofits that have already gone through the early period of struggle most prominently associated with the liability of newness (Aldrich \& Yang, 2012). Moreover, by electing to solely focus on new nonprofits with an IRS-rule date, nonprofit scholars will not only be uninformed about those entities that never obtain an IRS ruling but also be uninformed about the many attempts of starting new nonprofits that were halted earlier in the process. This selection bias clearly becomes an issue if the goal is to better comprehend and explain while some nonprofit founding attempts succeed when others do not (Andersson, 2017).

Second, this research has helped to contribute to the perspective that nonprofit founding can be denoted as a process made up by multiple undertakings that transpire over time. This temporal dimension, which is in line with how the nonprofit life cycle literature approaches the notion of founding, also alludes to the possibility of interconnectedness among the different undertakings. In their ethnographic study of the emergence of a new nonprofit organization, Avery C. Edenfield and Fredrik O. Andersson (2018) show how the undertakings that characterized and shaped the earliest stage in the founding process have implications for what would characterize and shape the subsequent stage(s). The notion that organizations are frequently, and deeply, impacted by prior experiences and events is sometimes referred to as organizational imprinting (Bryant, 2014), and illuminates that what happened early in the founding process is vital to comprehend the trajectory and undertakings at any of the later stages in the process. Edenfield and Andersson's (2018) study, for example, illustrates how the path from having the idea and intent to start a new nonprofit to the stage where the organization is operational was far from straightforward or easy: "[t]he nonprofit sector is often perceived and presented as a place with low entry barriers where eager entrepreneurs can, rather effortlessly, create new organizations. However, we believe such a view grossly underestimates just how demanding it is to actually concretize the idea of a new social venture into something substantial" (p. 1042). Evidently, more research is needed to untangle and explain the notion of imprinting during the founding process, but what is clear is that such research must attempt to capture the undertakings of founding as early as possible.

Building on the above discussion, nonprofit scholars must begin employing additional and multiple indicators to capture and characterize the earliest stages of emergence in order to truly reflect the complexity of the nascent process of found- 


\section{Levine Daniel \& Andersson (2021)}

ing. However, given that 60 percent of founder perceptions either did not match at all with the administrative indicators, or matched some arbitrary perception, this survey data firmly illuminates the diversity and vibrancy of the nascent phase. From this, it is apparent that emerging nonprofits do not "signal" their existence uniformly, much as many nonprofits engage in various sense-giving strategies (Levine Daniel \& Eckerd, 2019). Nonprofit scholars must, therefore, engage in discussion and debate to propose what indicators are most useful for identifying and assessing the emergence of new nonprofits. These discussions must include the voices of nonprofit founders themselves to ensure scholars ascribe the appropriate meanings to founding and best capture the desired activity.

A final observation is that nonprofit entrepreneurship scholars must ensure clarity as well as transparency when studying nonprofit founding. To start, they must articulate the motivation for studying founding. Are they interested in the process itself? Are they trying to find a measure for organizational age? To this end, is the founding date an explanatory factor or a control? For example, IRS dates and other discrete measures certainly reveal something, even though they are unreliable proxies of nonprofit founding. Still, using IRS dates (or incorporation dates) as a proxy for age is most likely sufficient when operationalizing and utilizing age as a control variable, but it is insufficient when utilized as a dependent or explanatory factor of founding. The need for clarity and transparency is also highly relevant for those seeking to study nascent nonprofits, the entry and exit rates of new nonprofits, the liability of newness among new nonprofits, and any form of imprinting or impact on a nonprofit emanating from its early life stage.

As noted earlier, this study also generates additional questions that provide opportunities for future study. In addition to the conceptual challenges of identifying the boundaries of nascent nonprofits and the pre-emergence stage that appears to exist between perceived founding and discrete organizational milestones, there are also many methodological questions that must be answered. For example, even some indicators can be agreed to capture the early signs of nonprofit founding, how can this empirical data be identified and collected in our communities and beyond? Another question in urgent need of more research is when the founding process of a new nonprofit ends. That is, when is the nonprofit entrepreneurship process complete, and what indicators should be used to make this distinction? Perhaps, instead of using IRS or Canada Revenue Agency dates, for example, as the earliest possible point of founding, these events may signal the end of the founding stage. To date, we are unaware of any study having attempted to answer this particular question.

The focus of this research is on nonprofit founding, but the study also has practical implications. For example, an organization's management, staffing, and/or volunteer needs during its emergence and quest for formalization may differ once these milestones are reached, which affects human resources management. The organizational strategies employed during founding will also change as the organization matures. In addition, resource providers such as foundations or grantmaking organizations may restrict their activities to organizations that have reached formalized milestones, effectively shutting out organizations that are doing the work on the ground but fall short of an age or years-since-incorporation requirement.

This study had some limitations. The data set was unstable, a challenge common to entrepreneurship scholarship, as some organizations had already failed or closed before they could be reached with the survey. The study relied, in part, on survey data, which carries risks for reporting errors and recall bias. Finally, the DataArts sample and survey samples are both sub-sector specific, focused on nonprofit arts and culture organizations.

\section{CONCLUSION}

Nonprofit founding can be studied as a discrete event or an ongoing process. This study presents a nuanced view of nonprofit founding that highlights its multidimensionality and underscores the need to treat the phenomenon as a process. Using multiple administrative data sets, this article shows the shortcomings of "founding as event," as well as the chal- 


\section{Levine Daniel \& Andersson (2021)}

lenges associated with these data sets themselves. The voices of founders are elevated to demonstrate their conceptualization of the concept and offer insights into when and how to expand the operationalization of founding.

\section{ACKNOWLEDGEMENT}

The authors would like to thank DataArts: The data used for this report was provided, in part, by DataArts, an organization created to strengthen arts and culture by documenting and disseminating information on the arts and culture sector. Any interpretation of the data is the view of the researchers and does not reflect the views of DataArts.

\section{NOTE}

1. There was an attempt to only identify organizations that were formed after 2000 for the survey population, but errors in the original DataArts data led to some false positives.

\section{WEBSITE}

DataArts, www.culturaldata.org

\section{REFERENCES}

Akingbola, K. (2013). Resource-based view (RBV) of unincorporated social economy organizations. Canadian Journal of Nonprofit and Social Economy Research, 4(1), 66-85. doi:10.22230/cjnser.2013v4n1a133

Aldrich, H.E., \& Yang, T. (2012). What did Stinchcombe really mean? Designing research to test the liability of newness among new ventures. Entrepreneurship Research Journal, 2(3), 1-12.

Andersson, F.O. (2017). A new focus on nonprofitentrepreneurship research. Nonprofit Management and Leadership, 28(2), 249-258. doi:10.1002/nml.21271

Andersson, F.O., \& Ford, M. (2017). Entry barriers and nonprofit founding rates: An examination of the Milwaukee voucher school population. Nonprofit Policy Forum, 8(1), 71-90.

Appe, S. (2012). What about who is mapping and its implications? Comments on Brent Never's "The case for better maps of social service provision." Voluntas, 23(1), 204-212. doi:10.1007/s11266-011-9189-1

Appe, S. (2013). Deconstructing civil society "maps." Administrative Theory \& Praxis, 35(1), 63-80. doi:10.2753/atp 1084-1806350105

Barr, C. (2020). A post Covid-19 agenda for nonprofit \& social economy research. Canadian Journal of Nonprofit and Social Economy Research, 11(1), 1-4. doi:10.29173/cjnser.2020v11n1a373

Bess, G. (1998). A first stage organization life cycle study of six emerging nonprofit organizations in Los Angeles. Administration in Social Work, 22(4), 35-52.

Bilodeau, M., \& Slivinski, A. (1998). Rational nonprofit entrepreneurship. Journal of Economics \& Management Strategy, 7(4), 551-571.

Bryant, P.T. (2014). Imprinting by design: The microfoundations of entrepreneurial adaptation. Entrepreneurship Theory and Practice, 38(5), 1081-1102.

Carman, J.G., \& Nesbit, R. (2013). Founding new nonprofit organizations. Nonprofit and Voluntary Sector Quarterly, 42(3), 603-621. doi:10.1177/0899764012459255

Cordes, J.J., Steuerle, E., \& Twombly, E.C. (2004). Dimensions of nonprofit entrepreneurship: An exploratory essay. In D. Holtz-Eakin \& H.S. Rosen (Eds.), Public policy and the economics of entrepreneurship (pp. 115-152). Cambridge, MA: MIT Press.

Dollhopf, E.J., \& Scheitle, C.P. (2016). Explaining variations in the nonprofit founding process. Nonprofit Management and Leadership, 27(2), 261-272. doi:10.1002/nml.21248 


\section{Levine Daniel \& Andersson (2021)}

Edenfield, A.C., \& Andersson, F.O. (2018). Growing pains: The transformative journey from a nascent to a formal notfor-profit venture. VOLUNTAS: International Journal of Voluntary and Nonprofit Organizations, 29(5), 1033-1043.

Godfrey, P. (2011). Toward a theory of the informal economy. The Academy of Management Annals, 5(1), 231-277.

Grønbjerg, K.A., \& Clerkin, R.M. (2005). Examining the landscape of Indiana's nonprofit sector. Nonprofit and Voluntary Sector Quarterly, 34(2), 232-259. doi:10.1177/0899764005275379

Grønbjerg, K.A., Liu, H.K., \& Pollak, T.H. (2010). Incorporated but not IRS-registered: Exploring the (dark) grey fringes of the nonprofit universe. Nonprofit and Voluntary Sector Quarterly, 39(5), 925-945. doi:10.1177/0899764009342898

Grønbjerg, K.A., \& Paarlberg, L. (2001). Community variations in the nonprofit sector community variations in the size and scope of the nonprofit sector: Theory and preliminary findings. Nonprofit and Voluntary Sector Quarterly, 30(4), 684-706. doi:10.1177\%2F0899764001304004

Grønbjerg, K.A., \& Paarlberg, L. (2002). Extent and nature of overlap between listings of IRS tax-exempt registration and nonprofit incorporation: The case of Indiana. Nonprofit and Voluntary Sector Quarterly, 31(4), 565-594. doi:10 $.1177 / 0899764002238101$

Hasenfeld, Y., \& Schmid, H. (1989). The life cycle of human service organizations: An administrative perspective. Administration in Social Work, 13(3/4), 243-269.

Kachlami, H., Davidsson, P., Obschonka, M., Yazdanfar, D., \& Lundström, A. (2020). The regional employment effects of new social firm entry. Small Business Economics, 1-21. doi:10.1007/s11187-020-00345-9

Khovrenkov, I. (2016). Size-based analysis of charitable foundations: New evidence from Canadian data. Canadian Public Policy, 42(3), 337-349. doi:10.3138/cpp.2014-033

Khovrenkov, I., \& Gidluck, L. (2017). Uncovering research potential of administrative data on charitable foundations in Canada. Canadian Journal of Nonprofit and Social Economy Research, 8(2), 24-29. doi:10.22230/cjnser.2017v8 n2a248

Kim, M., \& Charles, C. (2016). Assessing the strength and weakness of the DataArts cultural data profile in comparison with the NCCS 990 data. Journal of Public Budgeting, Accounting and Financial Management, 28(3), 337-360. doi:10.1108/JPBAFM-28-03-2016-B003

Kim, M., \& Levine Daniel, J. (2020). Common source bias, key informants, and survey-administrative linked data for nonprofit management research. Public Performance and Management Review, 43(1), 232-256. doi:10.1080/153 09576.2019.1657915

Lecy, J.D., \& Van Slyke, D.M. (2013). Nonprofit sector growth and density : Testing theories of government support. Journal of Public Administration Research and Theory, 23(1), 189-214. doi:10.2307/23321089

Lecy, J.D., Van Slyke, D.M., \& Yoon, N. (2016). What do we know about nonprofit entrepreneurs? Results from a largescale survey. Amsterdam, NL: Elsevier BV. doi:10.2139/ssrn.2890231

Levine Daniel, J., \& Eckerd, A. (2019). Organizational sensegiving: Indicators and nonprofit signaling. Nonprofit Management and Leadership, 30(2), 213-231. doi:10.1002/nml.21383

Liu, G. (2017). Government decentralization and the size of the nonprofit sector: Revisiting the government failure theory. The American Review of Public Administration, 47(6), 619-633. doi:10.1177/0275074016631643

Moulton, S., \& Eckerd, A. (2012). Preserving the publicness of the nonprofit dector. Nonprofit and Voluntary Sector Quarterly, 41(4), 656-685. doi:10.1177/0899764011419517

Saxton, G.D., \& Benson, M.A. (2005). Social capital and the growth of the nonprofit sector. Social Science Quarterly, 86(1), 16-35. doi:10.1111/j.0038-4941.2005.00288.x

Sharpe, D. (1994). A portrait of Canada's charities: The size, scope and financing of registered charities. URL: http://sourceosbl.ca/sites/default/files/resources/files/sharpe_portrait_of_canadas_charities.pdf [October 14, 2020]

Smith, D.H. (1997). The rest of the nonprofit sector: Grassroots associations as the dark matter ignored in prevailing "flat earth" maps of the sector. Nonprofit and Voluntary Sector Quarterly, 26(2), 114-131. doi:10.1177/08997640 97262002 


\section{Levine Daniel \& Andersson (2021)}

Stevens, S.K. (2008). Nonprofit lifecycles: Stage-based wisdom for nonprofit capacity (2nd ed.). Long Lake, MN:

Stagewise Enterprises.

Stinchcombe, A.L. (1965). Social structure and organizations. In J.G. March (Ed.), Handbook of Organizations (pp.

142-193). Chicago, IL: Rand McNally.

Twombly, E.C. (2003). What factors affect the entry and exit of nonprofit human service organizations in metropolitan areas? Nonprofit and Voluntary Sector Quarterly, 32(2), 211-235. doi:10.1177/0899764003032002003

Young, D. (1983). If not for profit, for what? Lexington, MA: Lexington Books.

\section{ABOUT THE AUTHORS / LES AUTEURS}

Jamie Levine Daniel is an associate professor at the Paul H. O'Neill School of Public and Environmental Affairs at IUPUI. Email: jlevined@iupui.edu .

Fredrik O. Andersson is an associate professor at the Paul H. O'Neill School of Public and Environmental Affairs at IUPUI.Email: fanders@iu.edu . 